\title{
Between History and Heritage: Post-Colonialism, Globalisation, and the Remaking of Malacca, Penang, and Singapore
}

\section{Daniel P.S. Goh}

\begin{abstract}
The three cities of Malacca, Penang and Singapore share a century-long history as the British Straits Settlements, with similar multicultural traditions and urban morphology of dense shophouse districts. In the post-colonial period, these have been the basis for the production of heritage for urban renewal, civic identity formation, and international tourism. Yet, each city has approached the production of its history as heritage in different ways. The differences have been specified in terms of whether heritage production has been led by the state, market or civil society, and criticised as ideology or ambivalently interpreted as formative of identity in the face of globalisation. As colonial port-cities integrating into or becoming a new nation-state, I argue that the production of heritage in the three cities is driven by the politics of post-colonial identity interacting with the political economy of urban redevelopment. I argue that the production of heritage is one facet in the production of space and an increasingly important one in globalising Asian urbanisms. We can specify the differences in production of heritage space in the three cities in terms of the orientation of imagination and the ends of production. I show that the three city-states have been interpreting its history for heritage production in either Asian or cosmopolitan imaginations and configuring its heritage production for either political identity formation or economic product development, or a mix of both. The differences, I demonstrate, are caused by the differing politics of post-colonial identity and economic development involving the three cities.
\end{abstract}

KEYWORDS: heritage, global city, post-colonial, urbanisation, Malaysia, Singapore

\section{INTRODUCTION}

Hor over a CEntury from 1826 to 1946, the three port-cities of Malacca, 1 Penang and Singapore shared a common history as the Straits Settlements under British rule. Malacca and Penang were separated from Singapore in 1946 and eventually incorporated into the independent Federation of Malaya in 1957. Singapore belatedly joined the Federation, renamed Malaysia, along with the former British Borneo states of Sarawak and Sabah in 1963, but separated and became independent in 1965 . 
Through the 1970s and 1980s, Penang and Singapore both industrialised. The islands became heavily urbanised. In the 1990s and 2000s, Singapore instituted economic reforms to develop into a post-industrial financial hub. Urban redevelopment plans that adapted historical precincts in the city centre to new economic uses played a large part in transforming it into a global city. During this period, George Town, Penang's inner city centre, went into a slow decline, only recently reviving its economic fortunes and experiencing urban renewal after obtaining the UNESCO World Heritage City status. Malacca shared the World Heritage City status with Penang, which helped boost the developing tourist industry in the old trading town.

The shared 120-year history created similarities in cultural traditions and urban morphology in the three cities, such as hybridised Chinese, Indian and Eurasian festivals, and dense colonial shophouse districts unique to coastal cities in the region. These shared traditions have been the basis for the production of heritage for urban renewal, civic identity formation, and international tourism. Yet, each city has approached the production of its history as heritage in very different ways. How do we specify the differences in the production of heritage between the three cities? How can we explain the differences?

Given the geopolitical and economic legacies as colonial port-cities integrating into the new nation-state of Malaysia, or in the case of Singapore, becoming a nation-state, I argue that the production of heritage in the three cities is driven by the politics of post-colonial identity interacting with the political economy of urban redevelopment in the context of globalisation. I begin first by discussing two theoretical approaches to the production of history as heritage and evaluate current studies of heritage and urban redevelopment in the three cities. I draw on Henri Lefebvre (1991) to make a critique of the two approaches and argue that the production of heritage is one facet in the production of space and an increasingly important one in globalising Asian urbanisms.

We can specify the differences in production of heritage space in the three cities in terms of the orientation of imagination and the ends of production. In the remaining sections, I show that the three city-states have been interpreting its history for heritage production in either Asian or cosmopolitan imaginations and configuring its heritage production for either political identity formation or economic product development, or a mix in both dimensions. The differences, I demonstrate, are caused by the differing politics of post-colonial identity and economic development involving the three cities.

\section{The Production of Heritage Space}

Discussions of the politics of heritage can be divided into two approaches. The critical approach emphasises two things. First, heritage is essentially a commodity produced for a tourist or domestic cultural market. Second, in its production, 
heritage also reflects the dominant culture and ideology on the part of the ruling elites. For Hewison (1989), the production of heritage fits into the cultural logic of late capitalism as a spectacular, hyper-real commodity that ransacks historical materials for superficial consumption in the present. Harrison (2005) argues that heritage is closely related to market ideologies and the power to impose one's view of the past. Many scholars see Singapore as a prime example of the hegemonic production of heritage for the market. Since the early 1990s, the state has actively sought to promote heritage as a "tourism commodity" (Chang 1997) by carving out the historic city centre into distinct multiracial zones, Chinatown, Kampong Glam and Little India, surrounding the civic centre of British colonial buildings. These ethnic neighbourhoods have been preserved in the ChineseMalay-Indian-Others racial grid of official multiracialism. As a result, they have become ethnic-themed precincts functioning as tourist attractions in the state's global city making plans (Chang 2000; Yeoh 2005).

Appiah (2009) locates the problem in the concept of "cultural patrimony" being tied to the state, which exercises power that destroys, physically or culturally, heritage objects that should properly belong to humanity. This problem with cultural patrimony takes on a pernicious twist in Malaysia as the nationstate's cultural policies have increasingly highlighted an idealised and indigenised Malay past centred on the glories and legends of pre-colonial Malacca (Cartier 1996; Worden 2010). With Malay heritage emphasised as cultural patrimony, Chinese and Indian cultural practices and buildings are denied the status of national cultural property and can be forcibly circumscribed and destroyed. Non-Malay or trans-ethnic histories are then easily erased from official discourse and policy, which emphasise Malay primacy in culture and politics (Mandal 2004; Ting 2009). Furthermore, the cultural policy is aligned to the bumiputera policy of promoting Malay socio-economic development through affirmative action in education and business.

The second approach is decidedly more ambivalent. Lowenthal's (1996: xi) classic argument is that while sharing the same field of the past, history "explores and explains pasts grown ever more opaque over time" but heritage "clarifies pasts so as to infuse them with present purposes". In this sense, heritage is more crucial to social life, as it plays an "essential role in husbanding community, identity, continuity, indeed history itself." For Lowenthal, heritage modifies history for the singular purpose of undergirding group identity rooted in exclusive legends and myths, drawing selectively and imprecisely from distant and generalised history to make for an intimate conflation of past with present (Lowenthal 1996: 139).

Application of the second approach as heritage studies emphasises the process of interpretation. For Howard (2003: 29-30), the constructed character of heritage is embraced and the student "proceeds to accept the challenge to manufacture an identity, to create heritage, but with an overt agenda and a transparent policy." The twin problems of market and power are acknowledged and 
they are to be managed in a dialogical manner with interpretation (Howard 2003: 187). In practical terms, interpretation is not so much about "bringing the past to life" but "trying to engage with our visitors in the present" (Hems 2006: 2), that is, a methodological problem rather than a historiographical or philosophical one.

Should heritage producers and managers focus on individual sites or should they weave them together in the interpretation of the whole town and its urbanism, for example by using trails and walks (Goodey 2006)? How should one approach the interpretation of lost ways of life such as industrial heritage as the city redevelops (Price 2006) or adaptively reuse buildings that used to house such heritage such as warehouses and factories in a manner sensitive to community participation and memory (Moore 2007)? Concretely for the developing countries of Southeast Asia, Henderson (2009) argues that heritage is not only cultural capital handed down from generation to generation, but is also social capital binding people together as well as political capital for nation building and economic development.

The successful application of George Town and Malacca for UNESCO listing has sparked recent revision of the early critical view of heritage production in Malaysia. Instead of seeing heritage production as beholden to the interests of a pro-Malay state promoting a pro-Malay market, scholars have emphasised the capacity of civil society to promote multicultural interests and compacts through local interpretations of heritage (Bideau and Kilani 2012; Nagata 2010; Perkins 2010). In Nagata's view, it was the polysemic nature of the heritage concept that allowed civil society activists to pull disparate interests together to "shift the focus of heritage away from historic traditions, invented or otherwise, to more universal issues beyond ancient ethnic and religious identity lines" (2010: 109).

On the other hand, scholars have remained critical and sceptical of the cosmopolitan interpretation of history in Singapore. As Johnson (2009: 189) puts it, international arts are valued over local practices, while "ethnic cultural expression and heritage precincts" only assume "real value when proscribed and profitable", hence Singapore as a "Cultural Capital" in the making is "ultimately unsustainable". Comparing three history and arts museums, Ooi (2010) criticises the state for reverse Orientalising the city-state as a cosmopolitan Asian society with benevolent governance, positive work ethic and superior moral values to place itself as a cultural capital in the region.

Switching between critical and interpretive approaches depending on whether state, market or civil society is driving the process of heritage production leads to one-dimensional analyses. Successful civil society ownership of heritage interpretation and driving of heritage production does not mean commodification has been moderated or power relations democratised. On the contrary, they have been reconfigured and repositioned in the social spatial field. On the other hand, capitalist market colonisation and the statist imposition of power may be less effective than dispersed commodification and enactment of capitalist power relations through civil society actors. 
The two approaches are missing the deeper issue. It is not heritage production per se that is the problem. The problem lies in the production of heritage space as a particular species of what Lefebvre calls the production of social space. Conceived as such, empty space "is actually merely a representation of space" (Lefebvre 1991: 190, italics in the original). The representation permits space to be conceived "as being transformed into 'lived experience' by a social 'subject" (Lefebvre 1991: 190), be it the market, state or civil society actors. This is the register in which the two theories of heritage production operate. The first, critical approach takes historical spaces as socialised spaces subverted by heritage production involving hegemonic ideologies. The second, interpretive approach takes heritage spaces as socialised spaces transformed using historical ideologies. Both assume a pre-existing empty space that bears socialisation by historical or cultural subjects.

By the production of heritage space, I mean the process of forging interrelationships between cultural things by positioning and working them into a physical pattern of relative order and disorder that shapes the practice of social life. The work of producing space involves the mutually reinforcing representation of space and representational space, the living weight of "imaginary and symbolic elements" in "the history of a people as well as in the history of each individual belonging to that people" (Lefebvre 1991: 41), or in short, the cultural memories and psychical habits of a community with regard to their lived spaces. Both representation of space and representational space make for a spatial practice to produce urban textures. The production of heritage space is a species of this work of producing space, in which the taken-for-granted cultural memories and habits of a community's spatial practice are appropriated into the representation of space. In other words, the production of heritage space is the production of space when representational space has been made reflexive and functional for the representation of space.

The two approaches to heritage production specify the differences in the production of heritage space to be explained. As I have pointed out, the two approaches have been analysing heritage production on the level of the representation of space rather than spatial practice. I find two dimensions of analysis particularly useful. First, the critical approach favours a cosmopolitan definition of heritage as cultural property, while the interpretive approach privileges the local and multi-scalar interpretations of heritage. Malacca, Penang and Singapore all promote a multicultural version of heritage conservation and production, but the difference is whether the heritage space producers imagine this multiculturalism as Asian, pitted against the West, or hybridising into cosmopolitan admixtures that is international in scope.

Second, the critical approach emphasises commodification as the end of heritage production, while the interpretive approach highlights identity formation. Contrary to studies critical of the overwhelming dominance of the heritage field by the developmental state in Singapore and celebrating the dynamism of 
civil society-led heritage production in Penang, the relationship between state and civil society in heritage production is actually more complex and contingent. What differentiates the three is whether the terms of state-civil society politics revolve around producing heritage space for tourist commodity development or post-colonial identity formation.

In terms of the imagination of its heritage space as Asian or cosmopolitan, Penang tends towards the latter, while Singapore the former, with Malacca in between. Penang and Singapore both treat heritage ambivalently as instrumental for identity formation and as commodity to sell the city, while Malacca focuses on the latter. As I argue in the next three sections, post-colonial politics and the political economy of urban redevelopment, both stemming from the contradictory representational spaces of port-city legacy and nationhood between 1930s and 1980s, influenced the varied production of heritage space in the three cities from the 1990s onwards.

\section{Malacca: Asian/Cosmopolitan Heritage Space as Commodity}

Malacca is the oldest settlement of the three cities. In the fifteenth century, it was the seat of a Malay sultanate. From the city, located at one of the narrowest points of the strategic Straits, the Malacca sultanate controlled a major leg in the lucrative spice trade route. It soon attracted Chinese traders, who settled in Bukit Cina (Chinese Hill) in the outskirts of the main town. As the city was the key link between the Southeast Asia archipelago and the Indian Ocean trade routes dominated by Muslim traders, the sultanate embraced Islam and Malacca became an important base from which the traders brought Islam to the region.

From the sixteenth century to nineteenth century, the Portuguese, Dutch and British conquered Malacca in succession. But the basic urban morphology established by the Portuguese was preserved. Colonial government buildings occupied the area around St Paul's Hill, where the destroyed old sultan's palace and colonial fort once stood, on the left bank of the river entrance. The main town, where trading activities took place, was situated on the right bank of the river and divided into ethnic quarters. However, by the nineteenth century, despite the segregation of the town into ethnic quarters, the ethnic communities, though retaining their communal traditions and identities, had formed relatively strong cross-ethnic business and social ties. The long centuries of mixed marriages fostered cultural hybridisation. The Malaccan Chinese had become Baba Chinese, the Indians became Jawi-Pekans, and the Portuguese Eurasians (Hussin 2007: 271-90).

In 1924, to commemorate the centenary of British rule, Malacca-based Europeans published The Town and Fort of Malacca. The publication came shortly 
after Singapore residents published the two-volume One Hundred Years of Singapore to commemorate the founding of that town. The latter comprised historical essays written by scholarly officials and professionals. In contrast, Town and Fort was an illustrated guidebook to the town for visitors. The Singapore Europeans were doing history, reflecting on the past looking at the city from a distance, while the Malacca Europeans were beginning to do heritage, looking up close at the town searching for the past.

Town and Fort opened with a historical sketch. The pre-colonial Malay and Chinese traffic was recognised, the Portuguese were portrayed as ravaging crusaders, and the Dutch seen as interested only in controlling the Straits and maintaining its trade monopoly. Unsurprisingly, the British were narrated as benevolent occupiers who preserved the "quaint, dreamy, Dutch-looking old town" (Malacca Centenary Committee 1924: 19). Brief descriptions followed of historical monuments such as the Stadthuys, the old fort, the ruins of St Paul's Church, memorial tablets, and tombstones with Armenian and Dutch inscriptions. A series of four articles completed the guidebook. The first narrated St. Francis Xavier and his doings in and out of Malacca. The second portrayed Christ Church as exemplary of Dutch architecture in Malacca, with references to Portuguese tombstones laid in the floor. The third described the Baba Chinese, emphasising how they have absorbed Malay, Indian and modern European cultural elements while preserving their Chinese customs to form a unique community. The last article touched on the Portuguese community.

The heritage enterprise was so popular with visitors that the Malacca Historical Society published a second edition of The Town and Fort in 1936, renaming it Historical Guide of Malacca. There were a number of notable additions. A new essay on the fall of Malacca to the Portuguese by the foremost scholar of Malay society of the period, R.J. Wilkinson, highlighted the mentality and life of the Malaccan Malays in their heyday. Historical monuments in the outlying districts featuring Malay forts and granite monoliths were described. A member of the Baba Chinese literati rewrote the essay on the Chinese. A short article on Malay mosques concluded the guide. These changes reflected two trends related to the upsurge of nationalist politics in the 1930s. First, the British were defining Malaya, with Malacca as the symbolic historical centre, as a quintessentially Malay country belonging to the Malays. Second, the Baba Chinese in the three settlements had re-identified themselves as Straits Chinese, a hybridised, modernised and progressive community loyal to the British who claimed political leadership of the native population.

\section{Between Malacca and Melaka}

When the Federation of Malaya became independent in 1957, independence was declared in Malacca. The new national compact, forged after the collapse of the Malayan Union and revolt by the communists, cemented the special 
position of the Malays. Non-Malays, making up a substantial minority, supported the promotion of bumiputera economic equality in return for full citizenship rights and political equality for non-Malays. The sultans became the constitutional heads of state. Malacca was of key symbolic significance because the new nation could claim an ancient historical link to the historically important Sultanate. Part of the national myth-making is that Malacca was "where it all began", in the words of a plaque unveiled by former Prime Minister Mahathir Mohamed in 1989, which has been the marketing slogan for official tourist promotion campaigns. It was also renamed Melaka, its name in Malay.

Worden (2010: 135) argues that Melaka's multicultural history and heritage landscapes have been "reclaimed to some extent by a Malay heritage" through the 1970s and 1980s, reflecting the symbolic reinvention of national identity as grounded in Malay culture and aligned with the pro-bumiputera provisions adopted after the Sino-Malay race riots of 1969. One thing that did not quite gel with this argument was the fact that the Federal Government approached the Dutch Government to help plan the restoration of the Stadthuys and other Dutch buildings in the 1980s. The plan, written by Dutch restoration architect Laurens Vis (1982), was subsequently published by the National Museum in Kuala Lumpur. Worden (2010: 138-9) explains this as the selective appropriation of Dutch colonialism and the downplaying of Portuguese and British colonialisms, because the Dutch had been portrayed in official narratives as a neutral power tolerant of Islam and a trading ally of the Malay states.

However, there are a few reasons for moderating Worden's argument. First, the Malay interpretation of history is not new, but stems from British colonial discourse on Malacca heritage as evident in the pre-War heritage guides. The same discourse also provides the space for hybridising nonMalay cultures in Malacca's heritage. Second, in his restoration proposal for the Dutch buildings, Vis ventured beyond the scope of his commission to recommend, among other spaces, the conservation of "the living area, the 'Chinatown' of Malacca, which is unique in the Far East because of its beautiful old houses of Dutch and Chinese origin" (1982: 65). Vis emphasised the charm of the houses along Jalan Tun Tan Cheng Lock, the former Heeren Street housing the Dutch gentry before the successful Straits Chinese merchants took over. This pointed to the significance of the renaming of the street after the Chinese founding father of the modern nation-state. Third, the housing of Malay exhibits in colonial buildings could be read as an exercise in asserting Malay presence in the heritage construction of Melaka in a hybridising manner. This development started in colonial times, as is evident in the 1936 Guide.

Furthermore, since the abortive attempts to clear the Chinese cemetery on Bukit Cina for urban development in the 1980s, which sparked a major controversy that galvanised the Chinese, community and heritage activists have organised to advance the equality of interest and stakeholding of non-Malays in the 
conservation and production of heritage in and around the historic town. That the activists were successful in putting their point across could be seen in the unsuccessful attempt by the authorities to put Malacca on the World Heritage list in the late 1990s, which were criticised by UNESCO for neglecting minority communities (Worden 2010: 143). Over-development that threatened to transform Malacca into a high-rise and mega-mall landscape and land reclamation that destroyed the historic waterfront for development were also reasons for the rejection in the late 1990s and for another rejection of an earlier application in the 1980s (Lim and Jorge 2005: 353-4).

The latter indicates that the real underlying cause for the heritage politics in Malacca is rapid economic modernisation favouring the growth of a Malay rentier class. Because the urban economy is concentrated on trading, the Malaccan Chinese middle-class comprises more merchants and entrepreneurs than professionals. The issue for the Chinese is therefore their share in the economic benefits of urban redevelopment policy. The problem was that the development plans for Malacca, whether they involved taking over heritage buildings and precincts or new heritage-despoiling developments such as the building of golf courses, leisure resorts, waterfront hotels, and theme parks, was geared to reasserting Malay economic presence in Malacca and therefore excluded the Chinese. For the Malay ruling elites, especially those running the federal government, heritage conservation or not, Malacca should recover its pre-colonial status as the great trading city of Melaka.

There are Malay elites, particularly in the state and municipal governments, who have been open to working with the non-Malay communities. Discursively, the imagination of a pre-colonial Melaka provide for this, since the Chinese and Indians were already trading extensively and settling in the pre-colonial city. In other words, the great Melaka emporium is more Asian than it is exclusively Malay in imagination. This opened up space for the engagement with nonMalays that have been centred on harmonising heritage conservation with economic development.

In 1988, the Pacific Asia Travel Association (PATA) Malaysia Chapter, which represented multiracial business interests in the tourism sector, with the support of the state government and the Malacca State Development Corporation, requested the Association send a task force to advise on "tourism development, potential and future possibilities for Malacca, particularly in view of its rich historical and cultural assets" (PATA 1989: 1). Malacca was earlier that year declared an "Historic City" and laws were made to protect its heritage. The PATA task force appreciated that the state government was deeply committed to achieving official World Heritage listing for Malacca, but it noted that "the visible record of Malacca's history is thin, fragile, and not actually dramatic and not at all comparable to most international 'historic' sites" (Ibid.: 18). Therefore, instead of focusing on the historic core, the authorities should "think of the entire city as part of a larger ensemble” (Ibid.: 23). 
The task force highlighted the need to position Malacca in world history: "The European era is perhaps the core of the world image, and in the European era, it is the Portuguese achievement that is still the most memorable. In no way does this negate the importance of the origins of the Malay language, the spread of Islam and the struggle for freedom. But these are regional or national highlights and not of world significance" (PATA 1989: 16). In other words, Malacca should be imagined as both an Asian and cosmopolitan city. Significantly, the task force recommended the Malacca River as the "centre of history and interpretation" rather than the buildings themselves (Ibid.: 33), thus anchoring the heritage imagination in the city's traffic with the world, as "a centre of trade and commerce" (Ibid.: 50). The task force explicitly prefers "Malacca" as the name for "tourism purposes and for world recognition" rather than "Melaka” (Ibid.: 39).

\section{Developing Malacca for Heritage Tourism}

Through the 1990s and 2000s, the political contest over urban renewal was between those who sought to profit through urban redevelopment using an exclusively Malay imagination of Melaka and those who sought multiracial cooperation to develop heritage for tourism using the Asian-cosmopolitan imagination of Malacca. The former is heritage insensitive, but not heritage blind, as they would exploit heritage themes and sites for theme park, glitzy hotel and shopping mall development. The latter group followed the advice of the PATA task force and has gradually spruced up various heritage streets, embarked on tourist attraction projects such as the Jonker Walk night-market to bring nightlife to the city, and performed extensive renovation works to turn the River into a tourist Riviera.

In January 2008, the municipal council adopted the Conservation Management Plan containing many of the PATA task force recommendations, which helped clinch World Heritage listing in July that year. Among other things, the Council pledged to "increase the participation of all stakeholders including minorities in the planning and decision making process" through the formation of a residents' committee, the consensus of which members would need to be obtained for any conservation measures (Melaka Historical City Council 2008: 76). At another level, the Council promised to form "a smart partnership between the public sector, NGOs and tourist operators" to foster strategic cooperation for tourism management and development (Ibid.: 90). Four interpretive centres representing the Chinese, Malay, Indians and Eurasian communities were planned to "generate awareness to the quickly disappearing heritage" through "effective presentation to impart messages such as ethnic tolerance and harmony which all began in the state of Melaka" (Ibid.: 81).

But the multiracial group is not immune to leveraging heritage for large-scale development that is of dubious value and authenticity. In 2004, the state government announced the controversial construction of a 110-meter high observation 
tower on St Paul's Hill as a project to draw half a million tourists to the Malacca River area. The slim flagpole shaped tower with a revolving circular deck that moves up and down the centre pole is topped by a kris-like structure. This and other developments have drawn strong criticisms from conservationists outside of Malacca. In their pictorial tome celebrating local place and community identities, Malacca: Voices from the Street, Penang architect Lim Huck Chin and Portuguese architect Fernando Jorge (2005: 354) criticised the local authorities for being oriented towards "short-term commercial gains" harmful to "Malacca's unique historical fabric of architecture, communities and culture."

What the conservationists have failed to understand is that the Malaccans do not seek identity formation in the production of heritage space, as Malacca already has a fabled position in national, regional and world histories. The city's identity has already been sealed. The problem has long been one of economic revival and the commodity value of heritage for tourism now promises that the city could at last leapfrog from being stuck in the bygone era of maritime trade to a post-industrial service economy.

\section{Penang: Producing Cosmopolitan Heritage Space for Urban Revival}

The British established George Town in the northeast corner of Penang Island in 1786. Commercial shophouses were clustered in the town centre near the harbour lined up in a grid-like fashion. The Chinese and Chulias (Tamil Muslims) lived and worked in the commercial centre. Government buildings and European residences were located in the north-western part of town facing the northern coast. Most Malays and Jawi Pekans lived in the southern part of town and in village houses beyond the town. The town took shape largely according to the economic needs of the trading port (Hussin 2007: 141-155). Thus, the ethnic segregation was more a function of the economic division of labour than due to deliberate policy or racial differences. Though functionally separated, the different ethnic groups shared a common interest in seeing the new town prosper under British rule. Many Malaccan Baba Chinese and Jawi Pekan traders relocated to George Town. As hybridised locals well versed in the trade networks and cultures traversing the Straits, they played important roles as interethnic mediators. British traders also kept close relationships with Asians. The town quickly established itself as an important port in the Bay of Bengal.

The discovery of tin in Perak and Selangor in the 1840s turned Penang into an intra-Straits gateway to Peninsular Malaya. Tin transformed the town. George Town exploded with new Chinese migrants en route to the Peninsula. Laissez faire colonial government encouraged the growth of Chinese 'secret societies' and clan associations that managed the social and economic affairs of the new 
migrants. In 1857, the Municipal Council of George Town was established. The town grew denser. The different ethnic groups pulled together in an ever tighter urban mesh of crisscrossing economic and social relationships. It was a powder keg that exploded in 1867 when two Chinese secret societies and their Malay and Indian allies rioted over the control of tin mines across the channel and shut down the town.

1867 was also the year that the Straits Settlements became a Crown Colony ruled under direct supervision from London. This gave the three towns greater control of their affairs. The Settlements developed rapidly as regional and global trade boomed as the world with the expansion of the European empires and hence international capitalism. The rubber boom followed shortly, bringing great wealth to the Penang. Until Port Swettenham was greatly expanded in the interwar years to serve the Selangor hinterland and the federal capital Kuala Lumpur, Penang was the preeminent gateway entrepôt of Malaya.

In the Straits Settlements period, Penang became a secondary port to Singapore. However, as Turnbull (2009) points out, Penang was not a pale reflection of Singapore but a different society. It was much more Indian in character because of the Bay of Bengal trade than the Chinese-dominated Singapore. The British element was also more integrated into local society. Socially and culturally, the two towns diverged. Politically, Penang was more liberal than Singapore, as the latter, being the seat of colonial government in British Malaya, gradually developed a strong state apparatus to govern the larger and riotous Chinese population resident in the town and the disparate Malay states under British control. Penang held on to the previous era of laissez faire liberalism. Intellectual and educational activities and political movements thrived in Penang, especially with the growth of the non-European gentry and middle class.

After the War, the British dissolved the Straits Settlements and caused Penang to join the Malayan Union in 1946 and the Federation of Malaya in 1948. A brief secession movement and another to rejoin Singapore, both led by non-Malay elites, failed but they set a tone of ambivalence for Penang's relationship with the future nation. As the most economically dynamic state with the only non-Malay majority population in the Federation, Penang had an independent and rebellious streak. To appease the citizens that their local interests would be protected, George Town was granted city status by royal charter in 1957, months before Malaya became independent.

\section{National Development and the Decline of George Town}

1957 also saw the centenary celebrations of the Municipality of George Town. The City Council decided to prepare and publish its history to commemorate the centenary. Published in 1966, Penang, Past and Present, 1786-1963 was the citizens' first attempt at producing heritage space. Unlike Town and Fort, the book was purely a detailed account of the citizens' efforts in building up the city without specific monuments listed and highlighted in separate 
sections. However, the account was filled with local place names and the text augmented by many old and current photographs of city landmarks. This created a very concrete historical sense of the city that reflected everyday urban familiarity. The city was now animated by the agency of its past citizens laying roads, building precincts, constructing infrastructure, establishing urban services, resolving communal conflicts, and so on.

The account emphasised three ways to think about the space of Penang: as cosmopolitan rather than Asian, democratic, and ambivalently integrated into the colony or nation. First, importance was accorded to individuals for building up the city. The narrative, by following the municipal archives closely, inevitably gave pride of place to Europeans in the initial period of urbanisation. Non-European residents began to appear midway through the account to culminate in the clandestine evacuation of Europeans from Penang during the Japanese invasion, which was footnoted as having "gave rise to much unfavourable comment amongst the local population" (City Council 1966: 82). However, and significantly, other than Chinese individuals, many Europeans were listed among those who suffered under the Japanese. Asian individuals became prominent in the post-War account.

Second, the evolution of the municipal authority was narrated as a process in democratisation. The account linked the setting up of a committee of assessors in the 1820s to the institutionalisation of municipal government in England to expand the scope of "the principles of democracy" (City Council 1966: 14). The election of municipal commissioners in 1857 in the three towns of the Settlements was recounted as a dismal failure. Only Europeans voted in Singapore, while the election in Malacca was void due to the lack of voters. The Chinese in Penang voted for representatives opposed to government, but at least they voted and had a political position (Ibid.: 19). The narrative of democratisation climaxed in the last chapter with the granting of city status in 1957. Partisan elections to the City Council were appraised positively against detractors "who think only in terms of physical improvements rather than the evolution of a responsible local administrative body" (Ibid.: 96).

Third, the fundamental tension threaded through Penang, Past and Present was not the post-colonial narrative of interracial communalism versus multiculturalism. Instead, the account wrote of the tension between the municipal government and the colony or nation. This began in the late 1880s when the question was whether to make the boundaries of the municipality coextensive with the island. That it was not decided so was praised for preventing the municipal government from becoming an oppositional force representing Penang against Singapore (City Council 1966: 24). But the "friction" developed anyhow and the account proudly narrated the independent streak that municipal commissioners and citizens exhibited against the colonial government (Ibid.: 32, $33,36,39,48)$. The book warned that "the threat of being taken over by the State Government is not to be lightly regarded" in post-colonial times (Ibid.: 95). 
In 1969, the federal government suddenly revoked Penang’s free port status. The 1970s and 1980s saw George Town decline. The federal government focused on developing Port Klang, the former Port Swettenham, to service the development of Kuala Lumpur as Malaysia's primary city. The federal government directed economic development through its control over investment in communication, transport, education and health. The opposition Gerakan Party won the 1969 elections to become the state government, but it joined the ruling coalition in 1973. A compromise was obtained; Penang would not be neglected in the national development program. Penang was rapidly developed into a manufacturing hub for electronics and engineering.

However, the development took place largely in the southern parts of the island away from George Town and in Seberang Perai, the mainland enclave of Penang state. Younger residents moved out of the inner city into the suburbs. In 1974, to revitalise George Town, the state government launched a spectacular project to build the 65-storey KOMTAR shopping and commercial complex. The main tower was completed in 1988, but the project's fifth and last phase has yet to be launched, as of 2011. Hundreds of historical shophouses, schools and temples were demolished and damaged in the project, but it failed to revitalise George Town (Perkins 2008: 119-21).

\section{Saving George Town through Heritage}

As Lee, Lim and Nor'Aini (2008) argue, state policy did not affect the conservation of George Town and it was the unintended consequences of its economic development policy that saved George Town. Development plans to transform forested Penang Hill in 1990 galvanised civil society. Concerns regarding environmental degradation and deforestation were combined with discourses on the historical and heritage value of the Hill, especially as "a backdrop to the city”, to argue for its conservation (Friends of Penang Hill 1991: 39). The plans were shelved and the activists soon turned their attention to George Town. This intensified in 2000, when rent control in George Town was repealed and 60,000 long-time tenants began to leave, turning the inner city into a ghost town, while property owners planned to redevelop their shophouses for commercial use (Nagata 2010: 105).

The Penang Heritage Trust mobilised activists and local communities by holding a series of colloquia on the history of Penang in 2001 and 2002. Historian Tan Liok Ee wrote, "I was deeply moved by the sense of pride and palpable excitement with which a multiplicity of local voices and narratives claimed their place in the making and writing of the Penang story" (2009: 7). For Tan, the diverse voices tell a collective story of cosmopolitan Penang "finding confluences" as well as "engaging in contestation" in each historical conjuncture, from mercantile port city to economic integration in the nation-state to its going global again (2009: 24). The Penang Global Ethic Project was soon launched in 2006, featuring workshops, talks and "The Street of Harmony" heritage walk showcasing the 
cluster of temples, shrines, mosques and churches of different ethnic groups and faiths in the Jalan Masjid Kapitan Keling area. The shared UNESCO World Heritage listing with Malacca in 2008 was a natural culmination of the activist efforts.

George Town conservationists are however split between those who sought heritage conservation as an anchor for the Penang identity that is cosmopolitan, democratic and independent-minded and those who believe that a working partnership with the tourist industry is needed to revitalise the city and keep the heritage alive. Nanyang Folk Culture, a group of bilingual Chinese artist-activists, describes the former position best in their photography book, PENANGism. The book aims to give "the World an Imagination about Penang", to "increase the awareness of tolerance in cultural differences, the faith in democracy, and the mutual co-existence in our society", by portraying "elements of Penang" they believe "to have been vitalising Penang's uniquely urban attributes" (Nanyang Folk Culture 2011: 9).

Supported by the state government, the tourist industry has been seeking expansion of its base of operations in the northern beaches of Batu Feringgi to cultural tourism in George Town (Kahn 1997). A PATA task force was invited to conduct an assessment of Penang tourism in 2002. The members were "surprised and impressed with the extent and depth of the heritage, history and culture of Penang" and it "was a major hook upon which to hang future promotional campaigns", but they put up a red flag, "The Task Force detected an apparent aloofness and exclusivity or remoteness on the part of the [Penang Heritage Trust]" (PATA 2002: 13, 14).

The World Heritage listing has shifted attitudes among some activists and also the new opposition Democratic Action Party state government, such that a compromise between producing heritage for identity and for tourism is emerging. The listing, coveted by the activists as it compels the federal, state and municipal authorities to act to conserve George Town, also brings with it an influx of tourists. In 2009, conservationists organised the "Economics of Heritage Revitalisation" conference to learn from eight other World Heritage cities on collaboration between public authorities, the private sector and civil society (Khoo 2010). Khoo Salma Nasution, a veteran conservation activist and local historian who was one of the main organisers of the conference, became the new president of the Penang Heritage Trust in 2010. She believes that maintaining George Town's World Heritage status is "a balancing act" between heritage conservation and tourism (Chua 2010: 14), but one that is necessary to save George Town.

\section{Singapore: Gridlocked Heritage Space and The Developmental State}

Three years after Singapore was founded in 1819, Stamford Raffles gave detailed instructions for a town plan with tight urban grids. The left bank of the Singapore 
River, the main artery of commerce, was reserved for commercial buildings. To the immediate east was located the civic district and the European town. A plain to the north of the town buffered it from the native cantonment, hospital and the Indian washers' village to the northeast. East of the European town was the palace and mosque of Sultan Hussein, and Arab and Bugis kampongs. The Chinese and Indian Muslims were placed in their respective kampongs on the right bank of the river.

The resultant rigid racial segregation did not mean that the native residents submitted to its racial logic. As Pieris (2009: 159-161) shows, the natives developed alternative pluralisms that were expressed in multiple names for streets in different languages. Such hybridising vernacular pluralism in Singapore was not different from that found in Malacca and Penang, but the spatial expression of the pluralism between the three towns was significantly different. As Pieris (2009: 162, 161) puts it, George Town's natives “claimed their new geography as integral to their efforts at self-determination" while Malaccans "produced hybrid rural enclaves". In other words, hybridising vernacular pluralism found its way into the production of space in Penang and Malacca, in the lattices of the streets in the former and in the agglomerations of kampong neighbourhoods in the latter. On the other hand, the Singapore residents were only able to subvert the urban grid through vernacular naming and micro-spatial struggles over sidewalks (Yeoh 2003).

From 1867 onwards, with the establishment of the Straits Settlements and Singapore as the seat of colonial government, the urban grid hardened further. The building of new defences, the Government House, and the new prison strengthened the urban grid. As Pieris (2009: 213) argues, Singapore was being locked into a prison mode of producing space overlaid with a racial urban grid. The rubber boom before the First World War saw the mixing of neighbourhoods as the city centre became denser. However, the town expanded with grid logic, with the Chinese area pushing westwards to Tiong Bahru, Malay kampongs expanding eastward to Geylang, the Indians pushing northeastwards on Serangoon Road and the Europeans and Straits Chinese pushing northwestwards through Orchard Road.

As Britain's metropolis in the East, Singapore also became an experimental site for applying modern municipal and urban redevelopment ideas to the colony. In 1927, the Singapore Improvement Trust was established to develop modern sanitation, road infrastructure and public housing, and improve urban design. In 1936, the first public housing estate in Tiong Bahru was built, comprising thirty blocks of low-rise walk-up apartments. Construction continued apace after the War.

As Widodo (2004: 139) observes, the Tiong Bahru estate resembled progressive British New Town design principles: "small neighbourhoods", "maximum privacy between individual homes", "the need to promote health and to improve security through visibility and public surveillance." The apparent 
contradiction between maximum individual privacy and enhanced public surveillance is lost in Widodo's positive appraisal. Public housing was the metropolitan welfare state's extension of benevolent paternalism to the colonies, to transform natives into modern citizens who could eventually take up the burden of independence. The mixture of socialist and liberal principles was produced spatially to hone the better man. The natives would be civilised to adopt cultured public behaviour, while the home would be the private space of self-cultivation and domestic sociality.

\section{Post-colonialism Gridlocked}

Soon after it was elected into power in 1959, the People's Action Party government began to clear inner-city slums and move citizens into mass-constructed flats. Public housing construction accelerated with a vengeance after independence. In 1965, 23 per cent of the population lived in public housing flats. By 1990, the figure reached 87 per cent (HDB Annual Report 2007/2008: 60). Housing estates were located in two axial extensions westwards to the factories in Jurong and eastwards to the Airport, and in a ring surrounding the central catchment reservoirs. Citizens were encouraged to buy their flats, thereby creating "a property-owning democracy" (Kong and Yeoh 2003: 96), in which the citizens would be strongly committed to neighbourhood, society and country.

Public housing was geared to the virtuous cycles of economic development, heritage evolution and nation building. As the Chief Executive Officer of the Housing and Development Board wrote in 1982, in Our Heritage and Beyond, "public housing estates ... once equipped with the essential facilities, should provide maximum flexibility for people to evolve their own life-styles. Political stability and successful economic development schemes make it possible to upgrade physical environment in the housing estates. This in turn must upgrade the quality of life, reinforce political stability and facilitate economic development" (Liu 1982: 133). To influence the evolution of lifestyles and discipline public culture, the government used the racial logic encoded in the urban grid defining the inner city and mapped it unto the new urban spaces of the public housing estates. Community centres were established in every housing estate and government-appointed grassroots leaders organised language classes, cultural performances and other ethnic-themed events encouraging multicultural interaction. The hybridisation encouraged was not vernacular and organic, but mechanically structured in the racial grid of Chinese, Malay, Indian, and Others.

Intellectuals gave substance to the grid. In 1975, a symposium on cultural heritage featured talks by four prominent intellectuals on the heritage of the four races. V.T. Arasu, editor of the Tamil newspaper Tamil Murasu, spoke on Hindu culture. He noted that urban renewal and the resettlement of Indians had created "problems for the established temples operating on old patterns" and focused on rituals, but was hopeful that some were modernising by offering 
religious education and promoting dance, music and literature. Plans, he announced, were afoot to build "multi-purpose temples in new towns" to "cater to the artistic, cultural and social needs as well" (Arasu 1975: 15).

Arasu's criticism of the old patterns of Hindu culture represented the postcolonial government's approach to the production of heritage space. Temples, churches, and mosques were allocated space in the new towns to serve functions beyond religious practices. They would not only preserve the intangible heritage of the major racial groups in the new urban space, they would also help modernise the people. The government-led grassroots movement based in the community centres would then bring these modernising heritages together to facilitate the building of a multiracial nation. On the national level, the Ministry of Culture took on the task of synthesising the heritage development by producing encyclopaedias. Other than cultural practices, beliefs and practices, the Ministry's The Singapore Heritage magazine, published in the 1980s, featured streets in the downtown district with historical architecture, thereby cultivating a nascent heritage consciousness that harked back to the city centre for tangible heritage while promoting intangible heritage practices in the new towns.

\section{At the Margins of the Gridlock}

Urban redevelopment was ramped up further in the 1990s to transform the entire downtown area that was formerly gridlocked by Raffles' town plan into the global city centre of Singapore. Plans were made to preserve the educational buildings and old governmental buildings of monumental scale in the area for adaptive re-use, meaning to convert them into commercial hotspots, and museums and art galleries managed by the newly formed National Heritage Board under the Ministry of Culture. The underlying objective of the transformation was to produce monumental heritage spaces that would open up the urban communes and their thick cultural and social networks to global capital, migration and tourism flows.

Earlier plans were made to conserve Kampong Glam, the area around the Sultan Mosque, as the Malay district, Little India, and Chinatown as the Asian counterparts to the civic district. They were now to be integrated into the global city urban plan that would anchor Singapore's Asian national identity in tangible heritage, so that the citizens' heightened sense of nostalgia in the face of rapid development and dislocation could find a historical orientation in the old city (Yeoh and Kong 1996). At the same time, the preserved tangible heritage would serve as the foundational lattice for urban redevelopment of the gridlocked old city districts into ethnic-themed tourism precincts.

In 1998, the Singapore Tourism Board announced a grand project to remake Chinatown with colour-coded neighbourhoods, new "elemental" gardens and a "Village Theatre-Temple complex" that would be "recalling and revitalising the Chinatown spirit so fondly remembered by Singaporeans and visitors alike" (quoted in Kwok et al. 2000: 6). Activists reacted with criticisms that were 
furious by the standards of a country with a softening authoritarian regime. The Singapore Heritage Society championed the public cause and reminded the developmental state that Chinatown still possessed "a heritage - living traditions and communal spaces that continue and change up to the present day" (Kwok et al. 2000: 17). Instead of "trying to capture everything Chinese" in the village theatre and temple complex, the Society called for the Board to "let the population and resident groups decide what should be included in this communal building", so that tourists would be encouraged "to mingle with the local crowd and observe the living patterns of the Chinatown population" (Ibid:: 22). It also emphasised that the elemental garden idea was "grossly inappropriate and ignorant" because Chinatown "is multi-ethnic", "not a minority racial enclave" and "therefore, also not a destination of exotic oriental culture" (Ibid.: 22).

Significantly, the Society reminded the Board that many residents had relocated from shophouses into public housing flats in the area and that the residents had maintained their social life, commercial relationships and cultural practices in the town. They thus provide "precisely the types of cultural resources and experiences" Singaporeans could share with visitors (Kwok et al. 2000: 20). Elemental gardens and the village theatre and temple complex were scrapped, but the Chinatown residents remained segregated from the spruced up tourist zones. One could walk from a tourist street selling 'heritage' food and fashion to a residential centre a stone throw's away to get the same items at half the price. The re-articulation of the community's intangible heritage with the tangible heritage of place that the Society had called for ran against the history of racially gridlocked urbanism.

The gridlock extended into the 2000s. Heritage activists made little progress conserving living heritage spaces, except in cases where their conservation targets aligned with the urban planning objectives of the developmental state. Therefore, architects and Peranakan Chinese campaigning for the conservation of the old towns of Tiong Bahru and Joo Chiat respectively have met with some success. However, success brought with it gentrification, such that the quaint old world lifestyles activists had sought to preserve gave way to hipster cafes and well-heeled residents. On the other hand, long-time residents of old public housing estates in Queenstown and Rochor have been resettled for urban redevelopment, despite unpublicised protests and discontent.

A large part of the power of the state stems from its ability to control historical information, thereby limiting the ability of citizen activists and historians to produce their own heritage space (Dobbs 2010). Interestingly, the conservation movement that had galvanised citizens in recent years is focused on Bukit Brown Cemetery, the remaining public cemetery in Singapore where many colonial period luminaries are buried. The movement has seen intensive efforts in producing historical knowledge, turning the previously little-known cemetery into a veritable archive. Activists have also transformed it into a new vernacular heritage 
space through online publications and public talks and walks, thus forcing the government into engaging with the activists, off the grid.

\section{Conclusion}

History is not destiny, but the production of heritage space reinstitutes the dominant cultural logic of the past encoded in the urban fabric of the city in the material present, so that history defines destiny. The colonial urbanisms of the three British port cities have strongly influenced the way each city-state approached its inherited urban space in the contemporary period to deal with the exigencies of post-colonial identity and economic development. When colonial urbanism was highly segregationist, the post-colonial civic leaders tended to adopt an Asian orientation to imagine the city. When colonial urbanism facilitated cultural hybridity, the civic leaders tended to adopt a cosmopolitan imagination. Singapore and Penang form two ends of this spectrum from segregation to hybridity, with Malacca in between.

The post-colonial exigencies of nationalism and developmentalism mattered for all three city-states, but in different ways. Problematic engagements with nationalism focused heritage production on identity, while local developmentalism would compel the treatment of heritage as commodity. Assured of its historical identity and already the symbolic centre of the nation, Malacca is seeking to leapfrog into the contemporary post-industrial age on the back of cultural tourists washed ashore by globalisation. Penang, proudly cosmopolitan and democratic, but deeply ambivalent about its relationship with the nation, has to balance identity assertion and heritage tourism in order to save George Town from crumbling after decades of economic neglect. Singapore is still gridlocked by its colonial racial urbanism, as though Raffles' town plan is still in use, its citizens boxed into concrete flats laid out in new racial grids of intangible heritage, while the state faces the contradiction between multiracial national identity making and tourism-oriented urban redevelopment.

Heritage does not reflect the evils of capitalism or state power, nor does it reflect the natural or constructed identity of communities. Heritage is a symptom of the production of space in an era when capitalism, the state, and identity formation have become closely intertwined. Heritage and urban studies scholars have been arguing over the questions of what are heritage and the Asian city separately. The time is ripe to consider the two questions as stemming from the same theoretical problem. This is the problem of specifying the historicity of the post-colonial city in globalising Asia, just as the civic leaders have become reflexive and active in narrating their city's history and turning it into heritage.

The post-colonial city is finally coming of age and experimenting with urban forms to find its place in the world. We need to match its reflexivity without being 
caught up with its heritage production. We need to understand the historicity of the production of urban space, not just criticise or valorise the heritage constructions that are part of the production, as the issues run deeper than the apparent meanings and sentiments that the people are fighting over. It is nothing less than the spirits of capitalism that the people are seeking to domesticate in their material lifeworld.

\section{References}

Appiah, Kvame Anthony. 2009. Whose culture is it? In James Cuno (ed.), Whose Culture? The Promise of Museums and the Debate over Antiquities, pp. 71-86. Princeton: Princeton University Press.

Arasu, V. T. 1975. The Cultural Heritage of Singapore: Hindu Culture. Paper presented at the "Symposium on the Cultural Heritage of Singapore", pp. 1-16. Nanyang University, 29 November 1975.

Bideau, Florence Graezer and Mondher, Kilani. 2012. Multiculturalism, cosmopolitanism, and making heritage in Malaysia: a view from the historic cities of the Straits of Malacca. International Journal of Heritage Studies 18(6), 605-23.

Cartier, Carolyn. 1996. Conserving the built environment and generating heritage tourism in Peninsular Malaysia. Tourism Recreation Research 21(1), 45-53.

Chang, Tou Chuang. 1997. Heritage as a tourism commodity: traversing the tourist-local divide. Singapore Journal of Tropical Geography 18(1), 46-68.

Chang, Tou Chuang. 2000. Singapore's Little India: a tourist attraction as a contested landscape. Urban Studies 37(2), 343-66.

Chua, Rosalind. 2010. Taking tourism to the next level. Penang Economic Monthly 10(4), $8-14$.

City Council of George Town. 1966. Penang, Past and Present, 1786-1963. Penang: The Council.

Dobbs, Stephen. 2010. Traversing the boundaries of historical research: from the Singapore River to the Kra Canal. In Loh Kah Seng and Liew Kai Khuin (eds.), The Makers and Keepers of Singapore History, pp. 67-78. Singapore: Ethos Books.

Friends of Penang Hill. 1991. Penang Hill: The Need to Save Our Natural Heritage. Penang: Consumers Association of Penang.

Goodey, Brian. 2006. Interpreting urban heritage. In Alison Hems and Marion Blockley (eds.), Heritage Interpretation, pp. 9-32. London: Routledge.

Harrison, David. 2005. Introduction: contested narratives in the domain of World Heritage. In David Harrison and Michael Hitchcock (eds.), The Politics of World Heritage: Negotiating Tourism and Conservation, pp. 1-10. Clevedon: Channel View Publications.

Hems, Alison. 2006. Introduction: beyond the graveyard - extending audiences, enhancing understanding. In Alison Hems and Marion Blockley (eds.), Heritage Interpretation, pp. 1-8. London: Routledge.

Henderson, Joan C. 2009. The meaning, marketing, and management of heritage tourism in Southeast Asia. In Dallen J. Timothy and Gyan P. Nyaupane (eds.), Cultural Heritage and Tourism in the Developing World, pp. 73-92. London: Routledge. 
Hewison, Robert. 1989. Heritage: an interpretation. In David L. Uzzell (ed.), Heritage Interpretation, Volume 1: The Natural and Built Environment, pp. 15-23. London: Belhaven Press.

Howard, Peter. 2003. Heritage: Management, Interpretation, Identity. London: Continuum.

Hussin, Nordin. 2007. Trade and Society in the Straits of Melaka: Dutch Melaka and English Penang, 1780-1830. Singapore: National University of Singapore Press.

Johnson, Louise C. 2009. Cultural Capitals: Revaluing the Arts, Remaking Urban Spaces. Farnham: Ashgate.

Kahn, Joel S. 1997. Culturalizing Malaysia: globalism, tourism, heritage, and the city in Georgetown. In Michel Picard and Robert E. Wood (eds.), Tourism, Ethnicity and the State in Asian and Pacific Societies, pp. 99-127. Honolulu: University of Hawai'i Press.

Khoo Salma, Nasution. 2010. Studying others and staying unique. Penang Economic Monthly 10(1), 32-36.

Kong, Lily and Yeoh, Brenda S. A. 2003. The Politics of Landscape in Singapore: Constructions of "Nation". Syracuse: Syracuse University Press.

Kwok, Kian Woon, C.J. Wee Wan-Ling and Karen Chia (eds.). 2000. Rethinking Chinatown and Heritage Conservation in Singapore. Singapore: Singapore Heritage Society.

Lee, Lik Meng, Yoke Mui Lim and Yusuf Nor'Aini. 2008. Strategies for urban conservation: a case example of George Town, Penang. Habitat International 32(3), 293-304.

Lefebvre, Henri. 1991 [1974]. The Production of Space. Trans. Donald Nicholson-Smith. Oxford: Blackwell.

Lim, Huck Chin and Jorge, Fernando. 2005. Malacca: Voices from the Street. Malacca: Lim Huck Chin.

Liu, Thai-Ker. 1982. A review of public housing in Singapore. In S. Jayakumar (ed.), Our Heritage and Beyond: A Collection of Essays on Singapore, Its Past, Present and Future, pp. 133-53. Singapore: National Trades Union Congress.

Lowenthal, David. 1996. Possessed by the Past: The Heritage Crusade and the Spoils of History. New York: Free Press.

Malacca Centenary Committee. 1924. The Town and Fort of Malacca. Singapore: Methodist Publishing House.

Malacca Historical Society. 1936. Historical Guide of Malacca. Singapore: Printers Limited.

Mandal, Sumit K. 2004. Transethnic solidarities, racialisation and social equality. In E. Terence Gomez (ed.), The State of Malaysia: Ethnicity, Equity and Reform, pp. 49-78. London: Routledge.

Melaka Historical City Council. 2008. Conservation Management Plan for the Historic City of Melaka. Malacca: The Council.

Moore, Niamh M. 2007. Valorizing urban heritage? Redevelopment in a changing city. In Niamh Moore and Yvonne Whelan (eds.), Heritage, Memory and the Politics of Identity: New Perspectives on the Cultural Landscape, pp. 95-106. Farnham: Ashgate.

Nagata, Judith. 2010. "Elasticity" of heritage, from conservation to human rights: a saga of development and resistance in Penang, Malaysia. In Michele Langfield, William Logan and Máiréad Nic Craith (eds.), Cultural Diversity, Heritage and Human Rights, pp. 101-16. London: Routledge.

Nanyang Folk, Culture. 2011. PENANGism: A Visual Account of the 24 Hours of 1.1.11. Penang: The Culture. 
Ooi, Can-Seng. 2010. Histories, tourism and museums: re-making Singapore. In Michael Hitchcock, Victor T. King and Michael Parnwell (eds.), Heritage Tourism in Southeast Asia, pp. 82-102. Honolulu: University of Hawaii Press.

Pacific Asia Travel Association. 1989. Malacca: A Study of Tourism Potential. Singapore: The Association.

Pacific Asia Travel Association. 2002. Tourism Assessment in Penang. Bangkok: The Association.

Perkins, Gwynn. 2008. Contested Space: Cultural Heritage and Identity Constructions: Conservation Strategies within a Developing Asian City. Berlin: Lit Verlag.

Perkins, Gwynn. 2010. Interpreters of Space, Place and Cultural Practice: Processes of Change through Tourism, Conservation, and Development, in George Town, Penang, Malaysia. In Michael Hitchcock, Victor T. King and Michael Parnwell (eds.), Heritage Tourism in Southeast Asia, pp. 147-72.

Pieris, Anoma. 2009. Hidden Hands and Divided Landscapes: A Penal History of Singapore's Plural Society. Honolulu: University of Hawai'i Press.

Price, Jon. 2006. Interpreting industrial heritage. In Alison Hems and Marion Blockley (eds.), Heritage Interpretation, pp. 111-22. London: Routledge.

Tan Liok, Ee. 2009. Conjunctures, confluences, contestations: a perspective on Penang history. In Yeoh Seng Guan, Loh Wei Leng, Khoo Salma Nasution and Neil Khor (eds.), Penang and Its Region: The Story of an Asian Entrepôt, pp. 7-29. Singapore: NUS Press.

Ting, Helen. 2009. Malaysian history textbooks and the discourse of Ketuanan Melayu. In Daniel P.S. Goh, Matilda Gabrielpillai, Philip Holden, and Gaik Cheng Khoo (eds.), Race and Multiculturalism in Malaysia and Singapore, pp. 36-52. London: Routledge.

Turnbull, C.M. 2009. Penang's changing role in the Straits Settlements, 1826-1946. In Yeoh Seng Guan, Loh Wei Leng, Khoo Salma Nasution, and Khor, Neil (eds.) Penang and Its Region: The Story of an Asian Entrepôt, pp. 30-53. Singapore: National University of Singapore.

Vis, Laurens. 1982. The Stadthuys of Malacca: Restoration Proposal. Kuala Lumpur: National Museum.

Widodo, Johannes. 2004. The Boat and the City: Chinese Diaspora and the Architecture of Southeast Asian Costal Cities. Singapore: Marshall Cavendish.

Worden, Nigel. 2010. National identity and heritage tourism in Melaka. In Michael Hitchcock, Victor T. King and Michael Parnwell (eds.), Heritage Tourism in Southeast Asia, pp. 130-46. Copenhagen: Nordic Institute for Asian Studies.

Yeoh, Brenda S.A. 2003. Contesting Space in Colonial Singapore: Power Relations and the Urban Built Environment. $2^{\text {nd }}$ edition. Singapore: Singapore University Press.

Yeoh, Brenda S.A. 2005. The Global Cultural City? Spatial Imagineering and Politics in the (Multi) Cultural Marketplaces of South-East Asia. Urban Studies 42(5/6), 945-58.

Yeoh, Brenda S.A. and Kong, Lily. 1996. The notion of place in the construction of history, nostalgia and heritage in Singapore. Singapore Journal of Tropical Geography 17(1), 52-65. 